\title{
MEMBANGUN KESADARAN MASYARAKAT PINGGIRAN MELALUI BAITUL MAAL WAT TAMWIL (BMT)
}

\author{
Hoirul Amri \\ Dosen Fakultas Agama Islam (FAI) UM Palembang \\ Email : hoirul.amri16@gmail.com
}

\begin{abstract}
ABSTRAK
Penelitian ini membahas tentang membangun kesadaran masyarakat pinggiran melalui Baitul Maal Wat Tamwil (BMT). Hasil penelitian ini menunjukkan bahwa BMT merupakan lembaga keuangan syariah memberikan alternatif khususnya bagi masyarakat yang membutuhkan pelayanan jasa bank dengan pola syariah, bebas riba dan berbasis tolong-menolong. BMT dapat menjadi salah satu solusi bagi masyarakat pinggiran untuk memperoleh kesejahteraan dalam hidupnya, salah satunya dengan kesadaran untuk berpartisipasi aktif dalam BMT. Karena di dalam BMT dapat menjangkau masyarakat yang tidak mempunyai akses kepada pembiayaan oleh perbankan (unbankable) dan khusus bagi masyarakat kurang mampu yang notabene tidak begitu menarik bagi bank. Sedangkan bentuk penyaluran dana atau bantuan yang diberikan cukup beragam serta memberikan berbagai bantuan teknis seperti pelatihan, konsultasi, bantuan manajemen, dan bantuan pemasaran.
\end{abstract}

Kata Kunci : Masyarakat Pinggiran, BMT, Kemiskinan

\section{DASAR PEMIKIRAN}

Pertumbuhan populasi di kota-kota besar dan semakin meningkatnya urbanisasi, mengakibatkan muncul berbagai macam tipologi masyarakat dengan berbagai varian yang menempati kawasan-kawasan tertentu. Masyarakat dengan taraf ekonomi rendah, terpaksa harus tinggal di kawasan pinggiran kota dengan tingkat hunian seadanya. Kawasan pinggiran kota sampai saat ini senantiasa diidentikkan dengan kata "kemiskinan". Maka masyarakat yang tinggal dipinggiran kota sering diidentikkan dengan masyarakat pinggiran.

Pada umumnya mereka hidup dalam keterbatasan, dan ketidakberdayaan dalam menghadapi berbagai perkembangan dan perubahan yang terjadi. Ketidakberdayaan masyarakat pinggiran di samping disebabkan oleh masalah ekonomi, juga kurangnya akses masyarakat untuk memperoleh peningkatan kemampuan dan keterampilan masyarakat, termasuk informasi (Kusumaningrat, 2009: 149).

Kemiskinan dipandang sebagai kondisi seseorang atau sekelompok orang, lakilaki dan perempuan yang tidak terpenuhi hak-hak dasarnya secara layak untuk 


\section{2 | Hoirul Amri Membangun Kesadaran Masyarakat Pinggiran Melalui Baitul Maal Wat \\ Tamwil (BMT)}

menempuh dan mengembangkan kehidupan yang bermartabat. Dengan demikian, kemiskinan tidak lagi dipahami hanya sebatas ketidakmampuan ekonomi, tetapi juga kegagalan pemenuhan hak-hak dasar dan perbedaan perlakuan bagi seseorang atau sekelompok orang, dalam menjalani kehidupan secara bermartabat (Sriyana dan Fitri Raya, 2013: 30).

Islam menilai bahwa kemiskinan bukan disebabkan oleh kelangkaan atau kekurangan sumber daya, atau berkaitan dengan ketidaksinkronan mode produksi dan distribusi, tapi merupakan akibat dari penghamburan, kemewahan, pemborosan, dan pengabaian pembayaran apa yang sebenarnya menjadi hak milik masyarakat kurang mampu (Iqbal dan Mirakhor, 2015: 63).

Kemiskinan tidak hanya dapat diselesaikan oleh pemerintah, akan tetapi menjadi tanggungjawab bersama, baik itu pemerintah, swasta, lembaga profesi, perguruan tinggi maupun masyarakat itu sendiri. Permasalahan kemiskinan tersebut jika tidak diwaspadai serta di lakukan upaya dan langkah konkrit untuk menanggulanginya akan membawa akibat yang buruk seperti menurunya kualitas sumber daya manusia, timbulnya kecemburuan sosial, pengangguran, kerentanan, kriminalitas dan berbagai dampak negatif lainnya.

Salah satu upaya penanggulangan kemiskinan adalah dengan memutuskan mata rantai kemiskinan melalui kesadaran masyarakat dan pemberdayaannya salah satunya lewat BMT (Baitul Mat wat Tamwil). BMT sebagai lembaga keuangan syariah memberikan alternatif khususnya bagi masyarakat yang membutuhkan pelayanan jasa bank dengan pola syariah, bebas riba dan berbasis tolong-menolong. Walaupun kontribusi yang diberikan BMT dalam upaya pemberdayaan ekonomi rakyat masih tergolong kecil jika diukur dari kancah perekonomian nasional, namun jika dilihat dari upaya-upaya yang dilakukannya orientasi terfokus pada sektor ekonomi kerakyatan.

Berdasarkan paparan tersebut, maka diperlukan adanya kajian yang lebih komprehensif dan mendalam tentang bagaimana membangun kesadaran masyarakat pinggiran melalui BMT. Penelitian ini termasuk pada katagori jenis penelitian deskriptif, mengingat penelitian ini akan berupaya untuk menggambarkan kondisi dan kenyataan tentang membangun masyarakat pinggiran lewat BMT, berdasarkan fakta dan data sebagaimana adanya. 


\section{PEMAHAMAN}

\section{A. Pengertian BMT}

Baitul Maal Wa Tamwil (BMT) adalah balai usaha mandiri terpadu yang isinya berintikan Baitul Maal Wa Tamwil dengan kegiatan mengembangkan usaha-usaha produktif dan investasi dalam meningkatkan kualitas kegiatan ekonomi pengusaha kecil antara lain dengan mendorong kegiatan menabung dan menunjang pembiayaan kegiatan ekonominya. Dalam pengertian ini BMT menjalankan fungsi yang sama dengan Koperasi Jasa. Selain itu, BMT juga bisa menerima titipan zakat, infak, dan sedekah, serta menyalurkan sesuai dengan peraturan dan amanatnya (Soemitra, 2017: 473).

Dengan demikian keberadaan BMT dapat dipandang memiliki dua fungsi utama, yaitu sebagai media penyalur pendayagunaan harta ibadah, seperti zakat, infak, sedekah dan wakaf, serta dapat pula berfungsi sebagai institusi yang bergerak di bidang investasi yang bersifat produktif, sebagaimana layaknya bank (Soemitra, 2017: 474). Berdirinya BMT dilatarbelakangi oleh keinginan umat manusia untuk menghindari riba dalam kegiatan muamalahnya, memperoleh kesejahteraan lahir batin melalui kegiatan muamalah yang sesuai dengan perintah agamanya, yaitu bank yang berusaha sebisa mungkin untuk beroperasi berlandaskan kepada hukum-hukum Islam. Oleh karena itu, BMT yang bertujuan untuk mengatasi permodalan usaha mikro, kecil dan menengah berdasarkan syari'at Islam (Sudarsono, 2003: 97).

Menurut PINBUK BMT merupakan lembaga ekonomi rakyat kecil yang berupaya mengembangkan usaha-usaha produktif dan investasi dalam menbingkatkan kegiatan ekonomi pengusaha kecil dan berdasarkan prinsip syariah (Huda, dkk, 2016: 285). Pendirian BMT biasanya dilakukan dengan menggunakan sumber daya, termasuk dana atau modal, dari masyarakat setempat itu sendiri. Pendirian BMT memang cukup banyak yang dibantu oleh pihak luar masyarakat lokal, tetapi hal itu lebih bersifat bantuan teknis. Bantuan dari pihak luar sering bersifat konsepsional atau stimulan, umumnya dari lembaga atau asosiasi yang peduli BMT atau masalah pemberdayaan masyarakat (Amalia, 2009: 82).

Kehadiran BMT (Baitul Mal Watamwil) diharapkan mampu menjadi lembaga solidaritas sekaligus lembaga ekonomi bagi rakyat kecil untuk bersaing di pasar bebas. BMT (Baitul Mal Watamwil) berupaya mengkombinasikan unsur-unsur iman, taqwa, 


\section{4 | Hoirul Amri Membangun Kesadaran Masyarakat Pinggiran Melalui Baitul Maal Wat Tamwil (BMT)}

uang, materi secara optimum sehingga diperoleh hasil yang efisien dan produktif dan dengan demikian membantu para anggotanya untuk dapat bersaing secara efektif.

Sebagian besar BMT, sejak awal memang berbentuk koperasi karena konsep koperasi sudah dikenal luar oleh masyarakat dan bisa mmberi status legal formal yang dibutuhkan. Akan tetapi, ada pula BMT yang pada awalnya hanya bersifat organisasi kemasyarakatan informal, atau semacam peguyuban dari komunitas lokal (Amalia, 2009: 83).

BMT didirikan dalam bentuk KSM (Kelompok Swadaya Masyarakat) atau Koperasi. Sebelum usahanya, kelompok Swadaya Masyarakat mesti mendapatkan sertifikat operasi dari PINBUK (Pusat Inkubasi Bisnis Usaha Kecil). Sementara PINBUK itu sendiri mesti mendapat pengakuan dari Bank Indonesia (BI) sebagai Lembaga Pengembangan Swadaya Masyarakat (LPSM).

Sejak awal berdirinya, BMT dirancang sebagai lembaga ekonomi yang secara konsepsi dan secara nyata lebih fokus kepada masyarakat bawah yang miskin dan nyaris miskin (poor and near poor). BMT berupaya membantu pengembangan usaha mikro dan usaha kecil, terutama bantuan permodalan. Untuk melancarkan usaha membantu permodalan tersebut, yang biasa dikenal dengan istilah pembiayaan (financing) dalam khazanah keuangan modern, maka BMT juga berupaya menghimpun dana, terutama sekali berasal dari masyasrakat lokal di sekitarnya. Dengan kata lain, BMT pada prinsipnya berupaya mengorganisasi usaha saling menolong antar warga masyarakat suatu wilayah (komunitas) dalam masalah ekonomi (Amalia, 2009: 83).

Salah satu tonggak penting gerakan BMT adalah didirikannya Pusat Inkubasi Bisnis Usaha Kecil (PIBNUK) pada tahun 1995 oleh Ketua Umum MUI, Ketua Umum ICMI, dan Direktur Utama Bank Muamalat Indonesia. PINBUK memperkenalkan serta mempopulerkan istilah BMT. PINBUK pula yang paling giat mendorong pendirian BMT di berbagai wilayah, disertai dengan bantuan teknis untuk hal tersebut. PINBUK banyak mengadakan forum ilmiah, menerbitkan buku-buku petunjuk teknis, mengembangkan jaringan kerjasama, dan sebagainya yang memudahkan masyarakat mendirikan dan mengelola BMT secara baik (Amalia, 2009: 89).

BMT memiliki ciri-ciri utama sebagai berikut :

a) Berorientasi bisnis, mencari laba bersama, meningkatkan pemanfaatan ekonomi paling banyak untuk anggota dan lingkungannya. 
b) Bukan lembaga sosial tetapi dimanfaatkan untuk mengefektifkan penggunaan zakat, infaq dan shodaqoh bagi kesejahteraan orang banyak.

c) Ditumbuhkan orang banyak berlandaskan peran serta masyarakat di sekitarnya.

d) Milik bersama masyarakat kecil menengah kebawah dari lingkungan BMT itu sendiri, bukan milik orang-seorang atau orang dari luar masyarakat itu. (Djazuli, $2002: 184)$

Selain ciri utama di atas, BMT juga memiliki ciri khas sebagai berikut :

1) Sifat dan karyawan BMT bertindak aktif, dinamis, berpandangan produktif, tidak menunggu tetapi menjemput nasabah, baik sebagi penyetor dana maupun sebagai penerima pembiayaan usaha.

2) Kantor dibuka dalam waktu tertentu dan ditunggui oleh sejumlah staf yang terbatas, karena sebagian besar staf harus bergerak di lapangan untuk mendapatkan nasabah penyetor dana, memonitor dan mengawasi usaha nasabah.

3) Manajemen BMT diselenggarakan secara profesional dan Islami.(Djazuli, 2002 : 184)

Dalam konteks tujuannya, BMT bertujuan untuk mewujudkan kehidupan keluarga dan masyarakat di sekitar BMT yang selamat, damai dan sejahtera. Didirikannya BMT bertujuan untuk meningkatkan kualitas usaha ekonomi untuk kesejahteraan anggota pada khususnya dan masyarakat pada umumnya. Dalam rangka mencapai tujuannya, BMT berfungsi dan berperan diantaranya sebagai berikut:

1. Mengidentifikasi, memobilisasi, mengorganisir, mendorong dan mengembangkan potensi serta kemampuan potensi ekonomi anggota, kelompok anggota muamalat dan daerah kerjanya.

2. Meningkatkan kualitas SDI (Sumber Daya Insani) anggota menjadi lebih profesional dan islami sehingga semakin utuh dan tangguh dalam menghadapi persaingan global.

3. Menggalang dan memobilisir potensi masyarakat dalam rangka meningkatkan kesejahteraan anggota.

4. Menjadi perantara keuangan (Financial Intermediary) antara aghniya sebagai shohibul maal dengan duafa sebagai mudharib, terutama untuk dana-dana sosial seperti zakat, infaq, sedekah, wakaf dan hibah. 
Sedangkan prinsip operasional kerja BMT dikenal dengan lima prinsip atau 5 C yang dapat dijelaskan sebagai berikut :

1) Character. Penilaian terhadap karakter atau kepribadian calon peminjam untuk memperkirakan kemungkinan bahwa peminjam dapat memenuhi kewajibannya.

2) Capacity. Penilaian tentang kemampuan peminjam untuk melakukan pembayaran. Kemampuan diukur dengan catatan prestasi peminjam dimasa lalu yang didukung dengan pengamatan di lapangan atas sarana usahanya, seperti karyawan, mesin, sarana produksi, cara usaha dan sebagainya.

3) Capital. Penilaian terhadap kemampuan modal yang dimiliki oleh calon peminjam, diukur dengan posisi usaha atau perusahaan secara keseluruhan yang ditunjukkan oleh rasio keuangan dan penekanan pada komposisi modalnya.

4) Colateral. Jaminan yang dimiliki calon peminjam. Penilaian untuk lebih meyakinkan bahwa jika suatu resiko kegagalan pembayaran terjadi, maka jaminan dapat dipakai sebagai pengganti dari kewajibannya.

5) Conditions. Pihak BMT harus melihat kondisi ekonomi yang terjadi di masyarakat dan secara spesifik melihat adanya keterkaitan dengan jenis usaha yang dilakukan oleh calon peminjam. Hal tersebut dilakukan karena kondisi eksternal memiliki pengaruh yang cukup besar dalam proses berjalannya usaha calon peminjam dalam jangka panjang (Djazuli, 2002: 189).

Kelima prinsip tersebut dilakukan oleh BMT dalam hubungannya dengan para nasabah, terutama dalam hal proses peminjaman dana untuk mengetahui kondisi dan kemampuan para nasabah dalam memenuhi tanggungjawabnya sehingga dapat terjalin hubungan yang baik dan danya saling kepercayaan antara pihak BMT dengan para nasabah. Keterkaitan diantara faktor-faktor tersebut dengan produktivitas, terdapat hubungan yang tidak dapat terpisahkan. Suatu usaha akan dapat meningkatkan produktivitasnya apabila memperhatikan faktor-faktor yang dapat mendukungnya dengan baik.

BMT merupakan sebuah organisasi Kelompok Swadaya Masyarakat (pra koperasi) atau berbadan hukum koperasi, dalam bentuk kelompok simpan pinjam atau serba usaha. Oleh karena berbadan hukum koperasi, maka BMT harus tunduk pada Undang-Undang Nomor 25 Tahun 1992 Tentang Perkoperasian dan PP Nomor 9 Tahun 1995 tentang pelaksanaan usaha simpan pinjam oleh koperasi. Hal ini dipertegas oleh 
KEP.MEN Nomor 91 Tahun 2004 tentang Koperasi Jasa Keuangan Syariah.UndangUndang tersebut sebagai payung hukum berdirinya BMT (Lembaga Keuangan Mikro Syariah). Meskipun sebenarnya tidak terlalu sesuai karena simpan pinjam dalam koperasi khusus diperuntukan bagi anggota koperasi saja, sedangkan didalam BMT, pembiayaan yang diberikan tidak hanya kepada anggota tetapi juga untuk diluar anggota atau tidak lagi anggota jika pembiayaannya telah selesai (Dewi Yusuf, 2014: 73).

\section{Membangun Kesadaran Masyarakat Pinggiran}

Masyarakat pinggiran merupakan masyarakat yang tinggalnya di daerah-daerah pinggiran kota, yang hidup dalam kemiskinan dan terjebak pada keterbatasan membangun akses terhadap sumber daya ekonomi lainnya. Berdasarkan Hasil Survei Bank Dunia bekerja sama dengan Ford Foundation dengan Badan Pusat Statistik menegaskan bahwa kemiskinan terjadi karena krisis ekonomi dan mengakibatkan pengangguran, hilang penghasilan penghasilan, dan kesulitan memenuhi kebutuhan pokok (Amalia, 2009: 5).

Realitas di masyarakat menunjukan masih banyaknya masyarakat yang hidup dibawah garis kemiskinan.Penyebab utamanya mereka tidak mempuyai modal usaha.Selain itu kredit atau pembiayaan yang diharapkan lapis bawah, sulit untuk didapatkan karena mereka dipandang tidak bankable (tidak memenuhi kualifikasi perbankan) (Dewi Yusuf, 2014: 76). Bank sebagai pihak kreditur, sangat berhati-hati memberikan pinjaman. Selain karena faktor keuntungan, juga dikarenakan untuk memberikan stabilitas ekonomi nasional. Bank itu sangat terikat dengan peraturan pemerintah. Hal ini pulah yang menjadikan masyarakat miskin dan nyaris miskin (poor and near poor) sudah untuk dapat mengaksesnya. Selain itu, bank juga mewajibkan debitur atau nasabah memberikan jaminan untuk meminimalisir risiko kredit macet yang juga menghambat bagi masyarakat miskin disamping bunga pinjaman yang harus dibayarkan setiap bulannya.

Lebih dari itu, paradigma pembangunan harus bergeser dari pengutamaan pendekatan top down ke arah lebih memperkuat proses-proses pembangunan dari bawah yang lebih mengedepankan peran aktif masyarakat, yaitu menempatkan masyarakat sebagai titik sentral pembangunan (people central development) (Saharuddin, 2009: 17). Paradigma pembangunan yang semata-mata untuk pertumbuhan ekonomi yang sekedar 


\section{8 | Hoirul Amri Membangun Kesadaran Masyarakat Pinggiran Melalui Baitul Maal Wat \\ Tamwil (BMT)}

meningkatkan pendapatan perkapita harus diubah menjadi pembangunan yang bertujuan untuk pemberdayaan dan peningkatan kapabilitas masyarakat. Kekeliruan selama ini paradigma pembangunan didasarkan pada pemikiran kelompok liberal yang berujung pada disempowerment, impoverisment yang dapat menumbuhkan self disempowerment. Partisipasi dan emansipasi masyarakat harus menjadi tujuan pembangunan (Amalia, 2009: 103-104).

Berdasarkan berbagai masalah di atas, maka memberikan kesadaran bagi masyarakat pinggiran sebagai bagian dari masyarakat miskin merupakan keharusan karena masyarakat pinggiran dan miskin merupakan masalah sosial yang harus segera dicarikan solusinya. Karena kemiskinan dapat memicu munculnya kesenjangan dalam bermasyarakat (Dewi Yusuf, 2014: 69). Salah satu solusi yang ditawarkan adalah dengan pembangunan yang berorientasi kerakyatan dan berbagai kebijaksanaan yang berpihak pada kepentingan rakyat. Ekonomi kerakyatan dikembangkan sebagai upaya untuk lebih mengedepankan masyarakat. Dengan kata lain, konsep ekonomi kerakyatan dilakukan sebagai sebuah strategi untuk membangun kesejahteraan dengan lebih mengutamakan pemberdayaan masyarakat.

BMT merupakan salah satu bentuk pemberdayaan masyarakat miskin berbasis ekonomi kerakyatan. BMT bisa menjadi ladang bagi masyarakat pinggiran untuk meningkatkan kesejahteraan ekonominya. BMT sebagai lembaga mikro syariah sudah terbukti berhasil dalam usaha penyaluran dana pembiayaan kepada anggota atau nasabah. BMT berhasil menjangkau pihak-pihak yang selama ini dikatakan tak mempunyai akses kepada pembiayaan oleh perbankan (unbankable). Apalagi fokus dan target BMT merupakan bisnis skala kecil seperti kepada para pegang kecil yang kurang begitu menarik bagi bank (Kamil, 2016: 199). Bahkan hingga saat ini BMT telah menjadi sebuah lembaga keuangan profesional yang mampu menjangkau kelas ekonomi masyarakat paling bawah yang miskin dan nyaris miskin (poor and near poor) (Rizky, 2007: 20), dan BMT dapat menyediakan jasa keuangan yang sesuai dengan biaya yang dapat dijangkau oleh masyarakat miskin (marginal) dalam memperoleh akses keuangan (Dewi Yusuf, 2014: 76).

Adapun bentuk penyaluran dana atau bantuan yang diberikan cukup beragam. Ada yang murni bersifat hibah ada pula yang merupakan pinjaman bergulir tanpa dibebani biaya dalam pengembaliannya. Hibah sering berupa bantuan langsung untuk 
kebutuhan hidup yang mendesak atau darurat, dan bagi mereka yang memang sangat membutuhkan, di antaranya adalah; bantuan berobat, biaya sekolah, sumbangan bagi korban bencana, dan lain-lain yang serupa. Yang bersifat pinjaman bergulir biasa diberikan sebagai modal produktif untuk menjalankan usaha. Pada umumnya, dalam kaitan dengan pinjaman bergulir, BMT tidak hanya sekedar memberi bantuan dana, melainkan juga memberi berbagai bantuan teknis. Bantuan teknis tersebut dapat berupa pelatihan, konsultasi, bantuan manajemen, dan bantuan pemasaran (Amalia, 2009: 86).

Salah satu kendala pelaku usaha mikro adalah modal finansial yang kurang. Padahal modal finansial dapat dikatakan sebagai salah satu modal utama dalam membentuk suatu usaha. Kendala tersebut dapat teratasi dengan adanya lembaga keuangan mikro baik konvensional maupun syariah yang menyalurkan dananya kepada para pelaku usaha mikro. Sebagaimana lembaga keuangan mikro konvensional, lembaga keuangan mikro syariah BMT menyalurkan pembiayaannya kepada para pelaku usaha mikro sebagai anggotanya dengan mudah dan cepat.

BMT juga membantu melepaskan masyarakat dari jeratan renternir yang memberikan pinjaman dengan mengenakan suku bunga yang sangat tinggi. Pengelolaan produk pembiayaan perlu dilakukan dengan sebaik-baiknya karena berkaitan dengan tiga pihak. Pihak pemilik atau penyimpan dana, pihak bank sebagai perantara, dan pihak pengguna dana. Faktor kepercayaan perlu dibangun agar hubungan yang ada sudah terjalin bisa berjalan lancar. Sehingga ketiga pihak bisa mendapatlan maslahat dan adanya pembiayaan dan ada bentuk pertanggung jawaban atas penggunaan dana secara transparan.

Pembiayaan BMT kepada anggotanya diberikan dengan syarat yang mudah. Selain itu, BMT terjun langsung ke lokasi para pelaku usaha mikro untuk menyalurkan pembiayaanya sehingga para pelaku usaha mikro tidak perlu datang ke kantor BMT. Kemudahan tersebut menjadi keunggulan BMT dan umumnya diminati oleh para pelaku usaha mikro. Namun demikian BMT bertanggungjawab terhadap pembinaan anggotanya terutama anggota yang melakukan pembiayaan. Lebih dari itu, BMT berbeda dengan lembaga keuangan lain yang memberikan pembiayaan konsumtif sehingga perekonomian masyarakat cenderung konsumtif. BMT cenderung memberikan pembiayaan berupa modal kerja kepada masyarakat yang mempunyai usaha mikro agar 


\section{Hoirul Amri Membangun Kesadaran Masyarakat Pinggiran Melalui Baitul Maal Wat \\ Tamwil (BMT)}

masyarakat di dorong untuk lebih kreatif dan produktif. Sehingga dapat mengangkat perekonomian masayarakat menengah kebawah.

Apalagi sistem pembiayaan dalam BMT tidak menggunakan sistem bunga dan digantikan sistem bagi hasil. Hapusnya bunga dan melalui fasilitas pembiayaan investasi dengan sistem bagi hasil, masyarakat dan para pengusaha kecil khususnya mempunyai kesempatan yang luas untuk berusaha sehingga menumbuhkan ladangladang usaha baru. Berkembangnya ladang usaha baru akan membuka lebih banyak lagi kesempatan untuk meningkatkan pendapatan perkapita penduduk yang gilirannya akan meningkatkan produktivitas dan pertumbuhan ekonomi sehingga kesejahteraan penduduk semakin dapat dirasakan.

Meningkatnya kesejahteraan masyarakat menunjukkan bahwa pembiayaan yang disalurkan BMT dapat meningkatkan kesejahteraan masyarakat, yang berarti membantu sistem perekonomian di Indonesia terutama dalam pengentasan kemiskinan. Peran BMT dalam meningkatkan kesejahteraan masyarakat menunjukkan bahwa sistem ekonomi dengan prinsip syariah turut berperan dalam mengurangi kemiskinan di Indonesia, melalui peningkatan kesejahteraan masyarakat pelaku usaha mikro.

Walaupun demikian, peran BMT dalam mengetaskan kemiskinan sejauh ini belum terasa maksimal. Oleh karena itu, jika BMT dan stakeholders-nya mau berbenah dan lebih serius dalam memberdayakan masyarakat dan menekankan pada proses memberikan kemampuan kepada masyarakat akan menjadi berdaya, mendorong atau memotivasi individu agar mempunyai kemampuan atau keberdayaan untuk menentukan pilihan hidupnya. Orientasi usaha pemberdayaa ini bisa tertuju pada sektor usahanya, dengan memberikan motivasi atau dukungan dan peluang usaha serta tertuju kepada individu sendiri dengan memberikan pendidikan dan keterampilan atau pelatihan untuk memulai suatu usaha BMT merupakan bagian dari lembaga keuangan mikro telah lama menjadi sarana yang efektif untuk mengembangkan perekonomian rakyat dan memberdayakan rakyat miskin (Sriyana dan Fitri Raya, 2013: 33).

Sukron Kamil (2016: 203-204) menambahkan bahwa untuk pengembangan BMT ke depan, secara teoritik BMT juga bisa berperan dalam peningkatan dan perluasan layanan kesehatan bagi masyarakat menengah ke bawah, terutama masyarakat miskin. Caranya dengan meluncurkan program simbanan untuk asuransi kesehatan. Akan tetapi bidang layanan asuransi kesehatan yang diselenggarakan BMT harus 
mengisi bidang kosong yang belum disentuh lembaga/program lain seperti Program Jamkesmas Pemerintah dan LKC (Lembaga Kesehatan Cuma-Cuma) Dompet Dhuafa. Misalnya dengan meluncurkan produk simpanan asuransi kesehatan bagi kalangan miskin yang peruntukannya hanya untuk transportasi berobat, obat-obatan dan laboratorium di luar tanggungan Jamkesmas/Jamkesda, di luar tanggungan LKC dan untuk biaya dokter spesialis.

Selain simpanan untuk asuransi kesehatan bagi rakyat miskin atau menengah, BMT juga bisa berperan dalam pengadaan tempat tinggal/perumahan murah bagi rakyat miskin, baik dilakukan sendiri maupun bekerja sama dengan pemerintah atau CSR (corporate Social Responsibility) perusahaan. Meski saat ini belum, BMT dalam hal ini berpotensi untuk dikembangkan sebagaimana yang dilakukan Bank Grameen di Bangladesh. Bank kaum miskin ini digagas dan dikembangkan Muhammad Yunus, pelopornya yang mendapatkan Hadiah Nobel. Tentu saja dengan tidak harus menjadi bank (Kamil, 2016: 205).

BMT juga dalam menangani persoalan kredit macet pesertanya, pemberdayaan peserta yang terkena musibah, dan pemberdayaan perempuan, bisa juga mencontoh Bank Grameen. Di setiap cabangnya, bank yang bekerja di akar rumput ini memiliki keputusan enam belas yang harus dipegang teguh anggotanya. Antara lain mengembangkan prinsip; disiplin, kebersamaan, keberanian, kerja keras, tidak akan tinggal di rumah bobrok, dan selalu siap membantu satu sama lain. Karenanya jika seorarang peminjam tidak mampu atau tidak mau membayar, maka kelompoknya akan dianggap tidak layak memperoleh kredit yang lebih besar di tahun berikutnya, sampai masalah pembayaran bisa ditanggulangi. Ini membuat antar peminjam dalam satu kelompok terdorong untuk memecahkan masalah pembayaran anggotanya. Jika hal itu terjadi dalam kelompok, kelompok yang bermasalah bisa minta bantuan kepada kelompok lain (Kamil, 2016: 205).

\section{SIMPULAN}

Dari berbagai penjelasan di atas dapat disimpulkan bahwa; masyarakat pinggiran merupakan masyarakat yang tinggalnya di daerah-daerah pinggiran kota, yang hidup dalam kemiskinan dan terjebak pada keterbatasan membangun akses terhadap sumber daya ekonomi. Masyarakat pinggiran termasuk dalam masalah sosial yang harus ditanggulangi dan dicarikan solusi sesegera mungkin. Oleh karena itu, membangun 


\section{Hoirul Amri Membangun Kesadaran Masyarakat Pinggiran Melalui Baitul Maal Wat \\ Tamwil (BMT)}

kesadaran masyarakat pinggiran agar mampu meningkatkan kesejahteraan merupakan keharusan bagi semua pihak.

BMT termasuk salah satu solusi bagi masyarakat pinggiran untuk mengentaskan kemiskinannya terutama dalam aspek pendanaan. Karena dalam BMT mampu menjangkau kelas ekonomi masyarakat paling bawah yang miskin dan nyaris miskin (poor and near poor). Pendanaan yang diberikan BMT cukup beragam, bisa bersifat hibah atau pinjaman bergulir tanpa dibebani biaya dalam pengembaliannya (bunga). Pembiayaan BMT kepada anggotanya diberikan dengan syarat yang mudah. Selain itu, BMT terjun langsung ke lokasi para pelaku usaha mikro untuk menyalurkan pembiayaanya sehingga para pelaku usaha mikro tidak perlu datang ke kantor BMT.

\section{DAFTAR PUSTAKA}

Amalia, Euis, 2009. Keadilan Distributif dalam Ekonomi Islam; Penguatan Peran LKM dan UKM di Indonesia, Jakarta: Rajawali Press.

Dewi Yusuf, Sri, 2014. "Peran Strategis Baitul Maal Wa-Tamwil (BMT) dalam Peningkatan Ekonomi Rakyat, dalam Jurnal Al-Mizan, Volume. 10 Nomor 1, Juni 2014.

Huda, Nurul, dkk, 2016. Keuangdan Publik Islami; Pendekatan Teoretis dan Sejarah, Jakarta: Prenada Media Group.

Iqbal, Zamil dan Abbas Mirakhol, 2015. An Introduction to Islamic Finance; Theory and Practice, Terj. A.K. Anwar, Jakarta: Kencana Prenada Media Group.

Janwari, Djazuli HA. 2002. Lembaga-lemaga Umat sebuah Pengenalan. Jakarta :PT. Grafindo Persada.

Kamil, Sukron, 2016. Ekonomi Islam, Kelembagaan, dan Konteks Keindonesiaan; dari Paradigma Makro Ekonomi Hingga Realisasi Mikro, Jakarta: Rajawali Press.

Kusumaningrat, Hikmat, 2009. Memberdayakan Ekonomi Rakyat Kecil, Bandung : PT Remaja Rosdakarya Offset.

Rizky, Awalil, 2007. BMT; Fakta dan Prospek, Yogyakarta: UCY Press.

Saharuddin, 2009. "Pemberdayaan Masyarakat Miskin Berbasis Kearifan Lokal", dalam Jurnal Sodality; Jurnal Transdisiplin Sosiologi, Komunikasi dan Ekologi Manusia, Vol. 3, No. 1, April 2009.

Soemitra, Andi, 2017. Badan dan Lembaga Keuangan Syariah, Jakarta: Prenada Media Group.

Sriyana, Jaka, dan Fitri Raya, 2013. "Peran Bmt Dalam Mengatasi Kemiskinan di Kabupaten Bantul", dalam Jurnal INFERENSI, Jurnal Penelitian Sosial Keagamaan, Vol. 7, No. 1, Juni 2013.

Sudarsono, Heri, 2003. Bank dan Perbankan Syariah: Deskripsi dan Ilustrasi, Yogyakarta: Ekonisia. 